\title{
Long-term follow-up of conservative treatment of Charcot feet
}

\author{
Viviane Gratwohl ${ }^{1} \cdot$ Thorsten Jentzsch $^{1} \cdot$ Madlaina Schöni ${ }^{1} \cdot$ Dominik Kaiser $^{1} \cdot$ Martin C. Berli $^{1} \cdot$ Thomas Böni $^{1}$. \\ Felix W. A. Waibel ${ }^{1}(1)$
}

Received: 16 June 2020 / Accepted: 24 March 2021 / Published online: 7 April 2021

(c) The Author(s) 2021

\begin{abstract}
Background Charcot arthropathy $(\mathrm{CN})$ can ultimately lead to limb loss despite appropriate treatment. Initial conservative treatment is the accepted treatment in case of a plantigrade foot. The aim of this retrospective study was to investigate the mid- to long-term clinical course of $\mathrm{CN}$ initially being treated conservatively, and to identify risk factors for reactivation and contralateral development of $\mathrm{CN}$ as well as common complications in $\mathrm{CN}$.

Methods A total of 184 Charcot feet in 159 patients (median age 60.0 (interquartile range (IQR) 15.5) years, 49 (30.1\%) women) were retrospectively analyzed by patient chart review. Rates of limb salvage, reactivation, contralateral development and common complications were recorded. Statistical analysis was performed to identify possible risk factors for limb loss, $\mathrm{CN}$ reactivation, contralateral $\mathrm{CN}$ development, and ulcer development.

Results Major amputation-free survival could be achieved in $92.9 \%$ feet after a median follow-up of 5.2 (IQR 4.25, range $2.2-11.25$ ) years. $\mathrm{CN}$ recurrence occurred in $13.6 \% .32 .1 \%$ had bilateral $\mathrm{CN}$ involvement. Ulcers were present in $72.3 \%$. $88.1 \%$ patients were ambulating in orthopaedic footwear without any further aids. Presence of Diabetes mellitus was associated with reactivation of $\mathrm{CN}$, major amputation and ulcer recurrence. Smoking was associated with ulcer development and necessity of amputations.

Conclusions With consistent conservative treatment of $\mathrm{CN}$ with orthopaedic footwear or orthoses, limb preservation can be achieved in $92.9 \%$ after a median follow-up of 5.2 years. Patients with diabetic $\mathrm{CN}$ are at an increased risk of developing complications and $\mathrm{CN}$ reactivation. To prevent ulcers and amputations, every effort should be made to make patients stop smoking.

Level of Evidence III, long-term retrospective cohort study
\end{abstract}

Keywords Charcot $\cdot$ Neuroarthropathy $\cdot$ Long-term follow-up · Conservative treatment $\cdot$ Ulceration · Amputation · Recurrence

Felix W. A. Waibel

felix.waibel@balgrist.ch

Viviane Gratwohl

viviane.gratwohl@uzh.ch

Thorsten Jentzsch

thorsten.jentzsch@balgrist.ch

Madlaina Schöni

madlaina.schoeni@balgrist.ch

Dominik Kaiser

dominik.kaiser@balgrist.ch
Martin C. Berli

martin.berli@balgrist.ch

Thomas Böni

thomas.boeni@balgrist.ch

1 Divisions of "Prosthetics and Orthotics" and "Foot and Ankle Surgery", Department of Orthopedics, Balgrist University Hospital, Forchstrasse 340, 8008 Zürich, Switzerland 


\section{Introduction}

Charcot arthropathy $(\mathrm{CN})$ has first been described in 1868 by Jean-Martin Charcot [1]. As a chronic, often progressive disease, it affects mostly bones and joints, but also the surrounding soft tissues, and places the affected limb at an increased risk of lower extremity amputation $[2,3]$. The incidence of $\mathrm{CN}$ is $0.12-0.3 \%$ in diabetic patients [3-5]. At the time of Charcot`s first description, tabes dorsalis was thought to be the reason for CN [1]. Today, presence of polyneuropathy is known to be the prerequisite for diagnosis of CN [6]. Diabetic neuropathy has become the main risk factor to develop $\mathrm{CN}$ aside of the alcoholic polyneuropathy, kidney failure, spinal cord injury or other neuropathies [7]. The Charcot foot appears clinically mostly painless, swollen, flushed and overheated [8]. On conventional X-rays, there is a bony destruction, which typically progresses and results in foot deformities [9]. Those deformities can cause a variety of complications such as ulcers, soft tissue infection or osteomyelitis, with subsequent surgical treatment including amputation [10].

Common classifications of $\mathrm{CN}$ exist for clinical stages and anatomical patterns.

The Eichenholtz classification describes three clinical and imaging stages merging into each other [11]. Stage 1 is the active stage with destruction and fragmentation. Stage 2 is the healing stage with coalescence, sclerosis und sintering. Stage 3 is the chronic disease with completed bone remodeling. The original classification was later modified by Shibata et al. with an overheated, swollen, flushed foot with normal radiographic findings, but bone edema and stress fractures in MRI [12].

The Sanders and Frykberg classification defines five anatomical types of [13]. Type I involves the forefoot joints, Type II involves the Lisfranc's joints, the tarsometatarsal joint, including the metatarsal bases, cuneiforms, and cuboid, Type III includes Chopart's joints or the naviculocuneiform joints, Type IV contains the ankle with or without subtalar joint involvement and Type $\mathrm{V}$ involves the calcaneus [13].

The diagnosis of $\mathrm{CN}$ is made based on clinical signs supported by radiological imaging $[8,14]$. Presence of polyneuropathy or small fibre neuropathy is an indispensable condition to diagnose $\mathrm{CN}[6,15]$. In case of ambiguity or to exclude differential diagnoses such as infections, ulcerations, osteomyelitis, joint instability or fractures, MRI is recommended because of the highest diagnostic accuracy [8]. Laboratory investigations can help differentiating between $\mathrm{CN}$ and infection [14]. However, C-reactive protein, white blood cell count and erythrocyte sedimentation rate may also be elevated in active $\mathrm{CN}$ compared to non-active $\mathrm{CN}$ [16].
The aim of treatment is to save the affected limb and to maintain or restore mobility $[2,8]$. While there is a trend for more aggressive surgical treatment to achieve a plantigrade foot, the preferred treatment for active $\mathrm{CN}$ is activity reduction and off-loading in a total contact cast $[8,14$, $17,18]$. Off-loading is upheld until swelling and erythema have vanished and the difference in temperature is less than $2^{\circ}$ Celsius compared to the contralateral foot $[14,18]$. Protected weightbearing leads to a lower number of complications compared to unprotected weightbearing [19]. After transition to Eichenholtz stage 3, further treatment consists of individual orthopaedic shoes and prevention of complications. If conservative treatment fails or if it is impossible due to a non-plantigrade foot or instability, surgical treatment is indicated $[8,14,20]$. Most often, indications are recurrent ulcers, malalignement and soft tissue infection or even osteomyelitis. Procedures that are performed are simple ulcer debridements, open reductions, exostosectomies, arthrodesis with internal or external fixation, or finally amputations [8, 14, 20-23]. Amputations can be divided into minor and major amputations with the latter being procedures above the ankle joint [24]. In his benchmark analysis, Pinzur reported that $48.5 \%$ of $\mathrm{CN}$ patients can be treated conservatively [2].

But what is the clinical course of patients being treated conservatively? Complications such as ulcers, ulcer recurrence, amputation, $\mathrm{CN}$ reactivation, and contralateral $\mathrm{CN}$ involvement were investigated several times and showed a large variety of results. Ulcers occur in $37-67 \%$ [4, 25-31] and ulcer recurrence in $40-49 \%$ of cases [29, 30]. Amputation rates range from 8.9 to $25.7 \%$ and the annual amputation rate is $2.7 \%[23,27,30]$. Reactivation of $\mathrm{CN}$ has been seen in $7.1-33 \%[4,32,33]$. The contralateral foot is affected in $9.6 \%$ to $30 \%$ by $\mathrm{CN}[32,33]$. While there is a multitude of literature on short-term specific questions concerning $\mathrm{CN}$, there is only little evidence with rather small cohorts on midto long-term clinical follow-up for patients being treated for CN initially conservatively $[4,25,27-31,34,35]$. None of these studies contains information on all of the above-mentioned complications of $\mathrm{CN}$.

Therefore, the aim of this study was to describe the longterm outcome of patients being treated for $\mathrm{CN}$ initially conservatively. Primary outcome measure was the amount of major amputation-free survival. Secondary outcome measures were $\mathrm{CN}$ complications (ulcers, ulcer recurrence, $\mathrm{CN}$ reactivation, contralateral $\mathrm{CN}$ development) and surgical interventions. Further, we sought to determine risk factors for the occurrence of the above-mentioned $\mathrm{CN}$ complications as well as reactivation and contralateral $\mathrm{CN}$ development. Finally, we aimed to compare our results to literature on surgical treatment of $\mathrm{CN}$. In the author's opinion, it is appropriate to categorize these results as "long-term" as the study contains data of up to 20 years follow-up. 


\section{Patients and methods}

Balgrist University Hospital is a tertiary orthopaedic surgery referral center with a specialized unit for "Technical Orthopaedics" (treatment of CN, diabetic feet, chronic wounds, PAD complications, and amputations as well as prosthetics and orthotics).

Patient's data were retrospectively collected from medical records of patients during the period from January 1st 1995 to March 31st 2018 from the hospital's own information system. All patients were treated by or under direct supervision of one senior orthopaedic surgeon (T.B.). This study was approved by the local Research Ethics Committee (BASEC-Number 2018-00166).

Inclusion criteria were first time diagnosis of $\mathrm{CN}$ at the time of admission (by the Eichenholtz criteria [11] and confirmation by conventional X-rays) and conservative treatment initially, age $>18$ years, length of clinical follow-up of at least 2 years and informed patient consent obtained in accordance to the rules of the local Research Ethics Committee. Exclusion criteria were primarily surgically treated patients with $\mathrm{CN}$ due to a non-plantigrade foot, patients with insufficient documentation in the medical history, and clinical follow-up of less than 2 years. 253 patients were identified. 38 patients refused study participation and were excluded, 56 patients had inadequate patient documentation. In consequence, 159 patients with 184 affected feet were included in the study.

Primary outcome measure was the major amputationfree survival. Secondary outcome measures were $\mathrm{CN}$ reactivation, contralateral $\mathrm{CN}$ development, rates of ulcers and ulcer recurrence, rates of minor amputations and other surgical procedures related to the diagnosis of $\mathrm{CN}$.

On admission, diagnosis of $\mathrm{CN}$ was made using the Eichenholtz criteria [11] and confirmed by conventional $\mathrm{X}$-rays. Decision on conservative vs. surgical treatment was made under the supervision of T.B. Patients who needed immediate surgical correction were not analysed in this study. Patients with a non-collapsed plantigrade $\mathrm{CN}$ foot were conducted to conservative therapy. In 119 (64.7\%) feet, a total contact cast treatment was initiated which lasted on average 191 days (range 7-640 days) due to $\mathrm{CN}$ activity (Eichenholtz stage one or two) or ulcer presence in need of offloading. Total contact casting was performed by one of three nurses who have been trained in casting diabetic and Charcot feet throughout the whole observation period. In the remaining 65 (35.3\%) feet, orthopedic custom-made shoes or orthopedic serial-made shoes could be fitted immediately after diagnosis due to Eichenholtz stage three at initial presentation or patient`s refusal of total contact casting.
After total contact casting ended, 112 (60.9\%) feet were provided with orthopedic custom-made shoes, 5 (2.7\%) feet with orthopedic custom made shoes including an orthotic element for the purpose of hindfoot stabilization, 45 (24.5\%) feet with orthopedic serial-made shoes, $2(1.1 \%)$ feet with normal shoes (refusal of any kind of orthopaedic shoes), 5 (2.7\%) feet with an ankle foot orthosis (AFO), $1(0.5 \%)$ foot with a therapeutic shoe (patient's own choice due to the ease of use), and $1(0.5 \%)$ foot with a total contact cast (patient's own choice instead of a recommended AFO). 13 (7.1\%) feet needed a lower leg prosthesis due to major amputation. Besides the two patients (both had one $\mathrm{CN}$ foot) who refused any kind of orthopaedic footwear and $13(7.1 \%)$ feet undergoing major amputation, all remaining 169 feet were fitted with a custom molded depth-insole by a certified orthopaedic shoemaker (Swiss master craftsman education). CN reactivation was defined as bony reaffection diagnosed by the clinical criteria of Eichenholtz [11] and confirmed by conventional X-rays and MRI.

Statistical analysis was performed using STATA/IC (version 13; Stata Corp., College Station, TX, USA). The Chi-squared and Wilcoxon rank sum tests were used for comparison of groups. Kaplan-Meier survival estimates were calculated for $\mathrm{CN}$ reactivation and for contralateral $\mathrm{CN}$ development. Further, Kaplan-Meier survival estimates were calculated for amputation-free survival using SPSS (IBM Corp., Version 26, Armonk, NY, USA). A two-tailed T-Test was used to compare our primary and secondary outcome measures to the results of surgical literature. Values with $p<0.05$ were considered statistically significant.

\section{Results}

Patient`s demographics are summarized in Table 1.49 (30.8\%) patients were female, 77 (41.8\%) feet were left feet. $21(13.2 \%)$ patients died during follow-up after a median follow-up of 5.2 (IQR (interquartile range) 4.25, range 2.2-11.25) years after initiation of treatment. Median age at the time of first diagnosis of $\mathrm{CN}$ was 60.0 (IQR 15.5) years.

\section{Clinical stage and sanders type}

According to the modified Eichenholtz classification [11, 12 ], $12(6.5 \%)$ feet were in the prodromal stage, $89(48.4 \%)$ feet in stage 1, $18(9.8 \%)$ feet in stage 2 and $53(28.8 \%)$ feet in stage $3.12(6.5 \%)$ feet were at the stage of infection. Table 2 summarizes clinical and anatomical distribution at initial diagnosis and at reactivation. 
Table 1 Patients demographics $(n=159)$

\begin{tabular}{|c|c|}
\hline Variable & Median (IQR) \\
\hline Age (years) & $60(15.5)$ \\
\hline Duration of follow-up (years) & $\begin{array}{l}5.2(4.25, \text { range } \\
2.2-11.25)\end{array}$ \\
\hline $\operatorname{BMI}\left(\mathrm{kg} / \mathrm{m}^{2}\right)$ & $28.7(2.7)$ \\
\hline Variable & Number (percent) \\
\hline Women & $49(30.8 \%)$ \\
\hline Death $(n)$ & $21(13.2 \%)$ \\
\hline Diabetes & $115(72.3 \%)$ \\
\hline Type 1 & $17(10.7 \%)$ \\
\hline Type 2 & $98(61.6 \%)$ \\
\hline Smoker & $49(30.8 \%)$ \\
\hline $\mathrm{pAVK}(\mathrm{n})$ & $36(22.6 \%)$ \\
\hline Chronic kidney failure & $36(22.6 \%)$ \\
\hline \multicolumn{2}{|l|}{ Cause of Neuropathy } \\
\hline Diabetic & $129(70.1 \%)$ \\
\hline Vitamin B12 deficiency & $4(2.2 \%)$ \\
\hline Pharmacotoxic & $1(0.5 \%)$ \\
\hline Ethyltoxic & $16(8.7 \%)$ \\
\hline Spinal & $4(2.2 \%)$ \\
\hline Inflammatory & $3(1.6 \%)$ \\
\hline Idiopathic & $27(14.7 \%)$ \\
\hline
\end{tabular}

Table 2 Clinical and anatomical stage initially and at reactivation

\begin{tabular}{ccc}
\hline & Initial $(n=184)$ & Reactivation $(n=25)$ \\
\hline Clinical stage (mod. Eichenholtz [12, 40]) & \\
Stage 0 & $12(6.5 \%)$ & $0(0 \%)$ \\
Stage 1 & $89(48.4 \%)$ & $20(80.0 \%)$ \\
Stage 2 & $18(9.8 \%)$ & $5(20.0 \%)$ \\
Stage 3 & $53(28.8 \%)$ & $0(0 \%)$ \\
Infection & $12(6.5 \%)$ & $0(0 \%)$ \\
Anatomical stage (Sanders and Frykberg [38]) & \\
Type 1 & $25(13.6 \%)$ & $1(4.0 \%)$ \\
Type 2 & $87(47.3 \%)$ & $6(24.0 \%)$ \\
Type 3 & $56(30.4 \%)$ & $6(24.0 \%)$ \\
Type 4 & $11(6.0 \%)$ & $9(36.0 \%)$ \\
Type 5 & $5(2.7 \%)$ & $3(12.0 \%)$ \\
\hline
\end{tabular}

\section{Reactivation}

In $25(13.6 \%)$ feet, reactivation was detected clinically and confirmed by MRI. Median time to reactivation was 1.9 (IQR 2.2) years. Clinical and anatomical distributions are given in Table 2 while the Kaplan-Meier survival estimate for reactivation-free survival is given in Fig. 1.

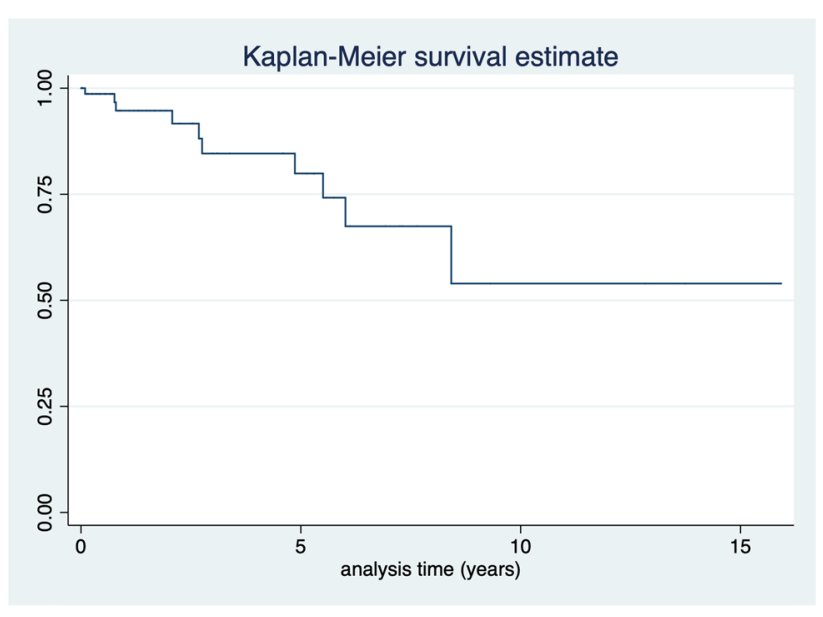

Fig. 1 Reactivation free survival

\section{Contralateral Charcot development}

$133(83.6 \%)$ patients had unilateral $\mathrm{CN}$ at the time of initial diagnosis, $26(16.4 \%)$ patients were affected bilaterally. $25 / 133(18.8 \%)$ patients developed $\mathrm{CN}$ on the contralateral side during follow-up. Median latency to contralateral $\mathrm{CN}$ development was 1.1 (IQR 2.8) years. In summary, 51/159 (32.1\%) patients had bilateral $\mathrm{CN}$ at the end of follow-up. Of note, three patients presented initially with contralateral 
major amputation without having contralateral $\mathrm{CN}$ prior to amputation. Kaplan-Meier survival estimate for contralateral CN development-free survival is given in Fig. 2.

\section{Mobility}

$119(74.8 \%)$ patients were still able to walk six blocks $(483 \mathrm{~m})$ without any aids at the end of the follow-up. 37 (23.3\%) patients were able to walk six blocks with aids only (walking sticks, walker). Two (1.3\%) patients were wheelchair-bound while one $(0.6 \%)$ was bed-ridden.

\section{Ulcers and ulcer recurrence}

At least one ulcer occurred in $133(72.3 \%)$ feet during follow-up: in 55 (29.9\%) feet at first diagnosis and in 78 (42.4\%) feet during follow-up. Median time to first time ulceration was 1.4 (IQR 2.4) years when patients presented without any ulcer initially. Ulcer distribution is shown in Table 3. A total of 89 (48.4\%) patients had ulcer recurrence. The median latency between initial treatment and ulcer recurrence was 1.7 (IQR 3.3) years.

\section{Surgical interventions}

78 (42.4\%) feet needed one or multiple CN-related surgical procedures during follow-up. The median latency between first consultation and surgery was 1.5 (IQR 4.1) years. One patient, who presented with an ulcer but without signs of infection initially, developed unexpected fulminant infection just 4 days after initial diagnosis and therefore, transtibial amputation had to be performed.

Surgical treatment was removal of exostoses in $10(5.6 \%)$ feet, ulcer debridement in 30 (16.4\%) feet, internal realignement arthrodesis in 8 (4.3\%) feet, and one-staged external

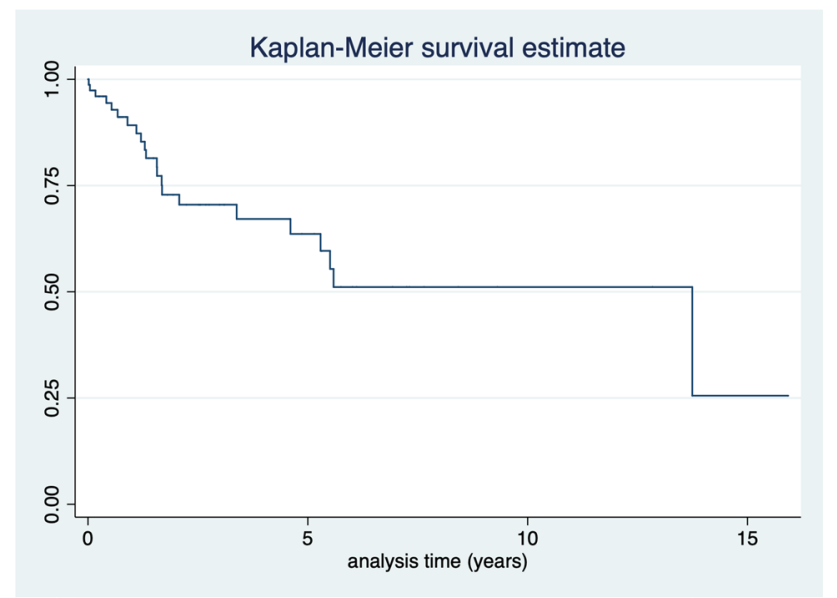

Fig. 2 Contralateral $\mathrm{CN}$ free survival realignment arthrodesis using the Ilizarov ring fixator in 18 (9.8\%) feet. In 35 (19.1\%) feet, amputations had to be performed. $22(12 \%)$ were minor amputations, $13(7.1 \%)$ were major amputations (Fig. 3, 4, 5 and 6). Median time to major amputation was 2.1 (IQR 4.5) years. Amputation details are shown in Table 4.

\section{Statistical analysis}

\section{$\mathrm{CN}$ reactivation}

Presence of Diabetes mellitus was significantly associated with $\mathrm{CN}$ reactivation $(p=0.022)$. Reactivation could be seen more frequently in type 1 diabetics $(6 / 18 ; 33 \%)$ than in type 2 diabetics $(15 / 113 ; 13 \%)$ or in patients suffering from $\mathrm{CN}$ without diabetes $(5 / 53 ; 8 \%)$. All other tested variables were not statistically associated with $\mathrm{CN}$ reactivation (Table 5).

\section{Development of contralateral $\mathrm{CN}$ during follow-up}

Female gender $(p=0.014)$ was significantly associated with development of contral CN during follow-up (13/57 (22.8\%) female feet vs 12/127 (9.4\%) male feet). All other tested variables were not statistically associated with Development of contralateral CN during follow-up (Table 6).

\section{Ulcer development}

$\operatorname{PAD}(p=0.049)$ and smoking $(p=0.002)$ were significantly associated with ulcer development. All other tested variables were not statistically associated with ulcer development (Table 7).

\section{Ulcer recurrence}

Patients developing ulcer recurrence were significantly younger (median age 57 years) than those without ulcer recurrence (median age 61 years) $(p=0.038)$. Further, smokers were more likely to develop ulcer recurrence than nonsmokers $(p=0.021)$ as were patients with $\operatorname{PAD}(p=0.003)$, and patients suffering from diabetes $(p=0.023)$. Sanders type was significantly associated with ulcer recurrence $(p=0.003): 56.9 \%$ feet with ulcer recurrence had Sanders type 2 deformity initially. All other tested variables were not statistically associated with ulcer recurrence (Table 7).

\section{Any amputation}

Diabetes $(p<0.001)$, PAD $(p<0.004)$, and smoking $(p<0.001)$ were significantly associated with the need for amputation. All other tested variables were not statistically associated with any amputation (Table 8). 
Table 3 Localization of ulceration at ulcer initial and ulcer recurrence and percentage of ulceration by Sanders Type

First time ulcer $(n=133)$

Ulcer recur-

rence $(n=89)$

\begin{tabular}{|c|c|c|}
\hline \multicolumn{3}{|l|}{ Localization of ulceration } \\
\hline Toe level $^{\mathrm{a}}$ & $84(63.2 \%)$ & $60(67.4 \%)$ \\
\hline Lisfranc level $^{\mathrm{b}}$ & $26(19.5 \%)$ & $16(18 \%)$ \\
\hline Chopart level $^{\mathrm{b}}$ & $14(10.5 \%)$ & $9(10.1 \%)$ \\
\hline Heel $^{\mathrm{b}}$ & $9(6.8 \%)$ & $4(4.5 \%)$ \\
\hline Percentage of ulceration per Sanders Type & $\mathrm{n}(\%)$ & \\
\hline \multicolumn{3}{|l|}{ Type $1(n=25)$} \\
\hline Toe level & $17(68 \%)$ & $14(56 \%)$ \\
\hline Lisfranc level & $2(8 \%)$ & $0(0 \%)$ \\
\hline Chopart level & $1(4 \%)$ & $0(0 \%)$ \\
\hline Heel level & $1(4 \%)$ & $0(0 \%)$ \\
\hline \multicolumn{3}{|l|}{ Type $2(n=87)$} \\
\hline Toe level & $40(46 \%)$ & $35(40 \%)$ \\
\hline Lisfranc level & $19(21.8 \%)$ & $12(13.8 \%)$ \\
\hline Chopart level & $8(9.2 \%)$ & $4(4.6 \%)$ \\
\hline Heel level & $0(0 \%)$ & $2(2.3 \%)$ \\
\hline \multicolumn{3}{|l|}{ Type $3(n=56)$} \\
\hline Toe level & $22(39.3 \%)$ & $10(17.8 \%)$ \\
\hline Lisfranc level & $5(8.9 \%)$ & $4(7.1 \%)$ \\
\hline Chopart level & $5(8.9 \%)$ & $5(8.9 \%)$ \\
\hline Heel level & $0(0 \%)$ & $1(1.8 \%)$ \\
\hline \multicolumn{3}{|l|}{ Type $4(n=11)$} \\
\hline Toe level & $4(36.4 \%)$ & $0(0 \%)$ \\
\hline Lisfranc level & $0(0 \%)$ & $0(0 \%)$ \\
\hline Chopart level & $0(0 \%)$ & $0(0 \%)$ \\
\hline Heel level & $1(9.1 \%)$ & $0(0 \%)$ \\
\hline \multicolumn{3}{|l|}{ Type $5(n=5)$} \\
\hline Toe level & $1(20 \%)$ & $1(20 \%)$ \\
\hline Lisfranc level & $0(0 \%)$ & $0(0 \%)$ \\
\hline Chopart level & $0(0 \%)$ & $0(0 \%)$ \\
\hline Heel level & $2(40 \%)$ & $1(20 \%)$ \\
\hline
\end{tabular}

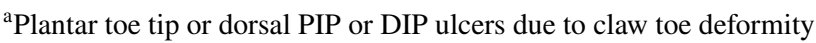

${ }^{\mathrm{b}}$ Plantar ulcers

\section{Major amputation}

Presence of diabetes $(p<0.001)$ and smoking $(p=0.008)$ were significantly associated with the need for major amputation. All other tested variables were not statistically associated with major amputation (Table 8).

\section{Power analysis}

A post hoc sample size calculation for one of the secondary outcomes, the association of major amputation and smoking yielded a power of $92.7 \%$ with an actual alpha of $2.7 \%$ (amputations in smokers $=19(35.2 \%)(n=54)$ versus amputations in non-smokers $=16(11.5 \%)(n=139)$.

\section{Discussion}

Clinical relevance of the present study is that initial conservative treatment of Charcot Arthropathy leads to limb salvage in $92.9 \%$ of the affected feet after a median of 5.2 years follow-up.

The present study contains $159 \mathrm{CN}$ patients with 184 affected feet and is not limited to $\mathrm{CN}$ in patients with diabetes. The patient number is the second largest in the literature to Jansen et al., who retrospectively analysed 173 patients and $176 \mathrm{CN}$ feet with diabetic $\mathrm{CN}$ over a substantial shorter period with a mean follow-up of 2.6 years [31]. Other longterm outcome reports on $\mathrm{CN}$ had either fewer patients or shorter follow-up (Bariteau et al. [25], Christensen et al. 
Fig. 3 Amputation free survival for the entire cohort
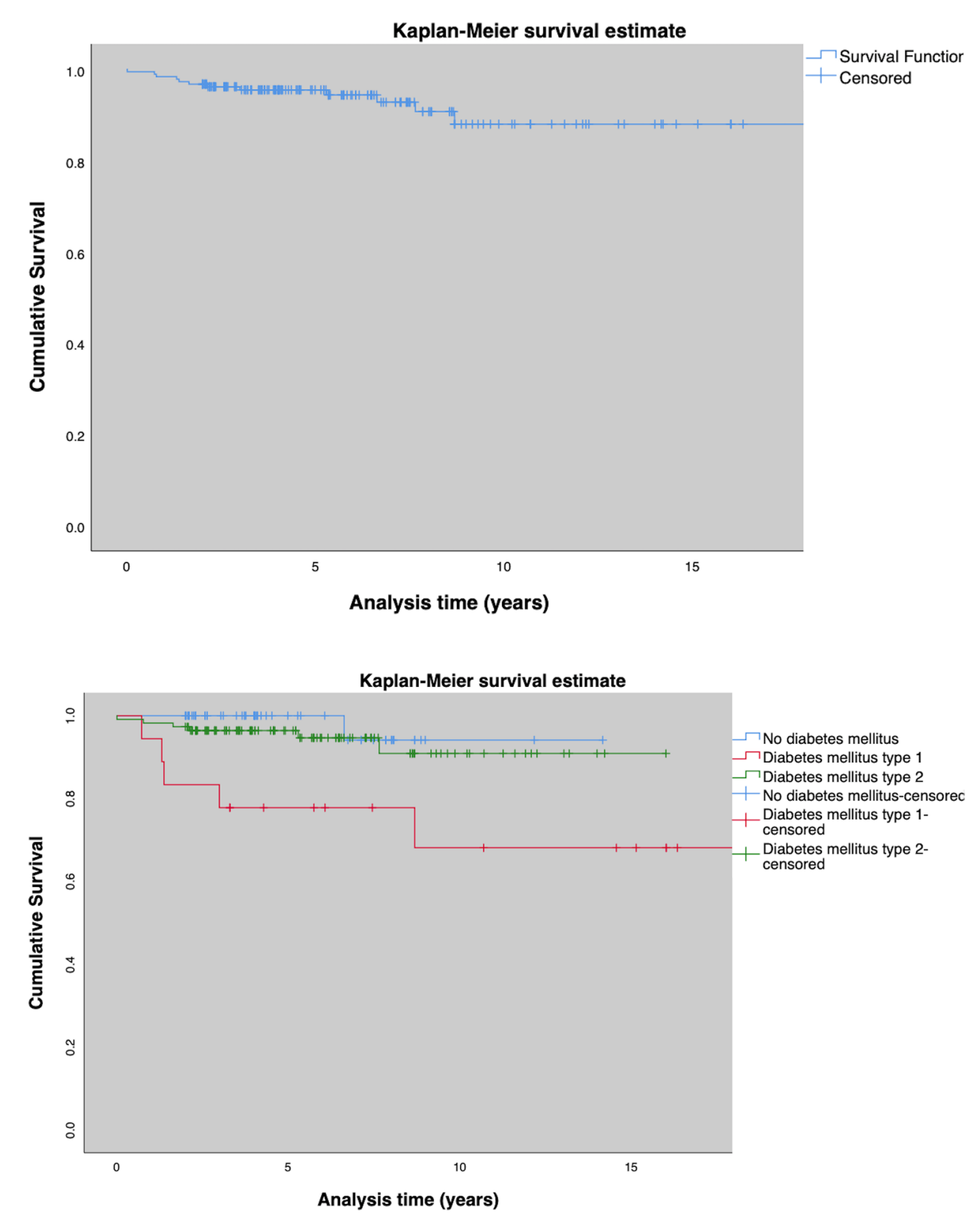

Fig. 4 Amputation free survival for patients without Diabetes, type 1 and type 2 diabetes
[35], Fabrin et al. [4], Saltzmann et al. [30]), longer follow-up periods but substantially fewer patients than the present work (Nilsen et al. [27], Pakarinen et al. [29]) or fewer patients and inconclusive or missing information on duration of follow-up (Bergis et al. [34], O'Loughlin et al. [28]). All of the above-mentioned studies lacked one or more outcome information given in this study (Table 9). Hence, in the authors opinion, the present study contains the most comprehensive results in the literature concerning conservative treatment of $\mathrm{CN}$ and therefore contributes substantially to the understanding of $\mathrm{CN}$ `s clinical course when treated conservatively. Further, it does not preclude patients with $\mathrm{CN}$ developing from other reasons than diabetes. Limitations of this study are the retrospective study design with possible occurrence of a collection and/or information bias. Further, we lack a surgical control group. Also, application of total contact casts by three different nurses might have led to a treatment. Though they were trained identically, individual handling of cast techniques might have occurred. Analysis of comparable literature did not reveal information on application of total contact casts. We assume that different institutions face the same staff variability in total contact casting and therefore consider this treatment bias comparable to those of prior literature. Finally, with performance of a post hoc sample size calculation for one of the secondary outcomes, data need to be interpreted with care because this post hoc sample size calculation is not valid for all tests. 
Fig. 5 Amputation free survival for patients with and without an ulcer at initial presentation
Fig. 6 Amputation free survival for patients with and without ulcer recurrence
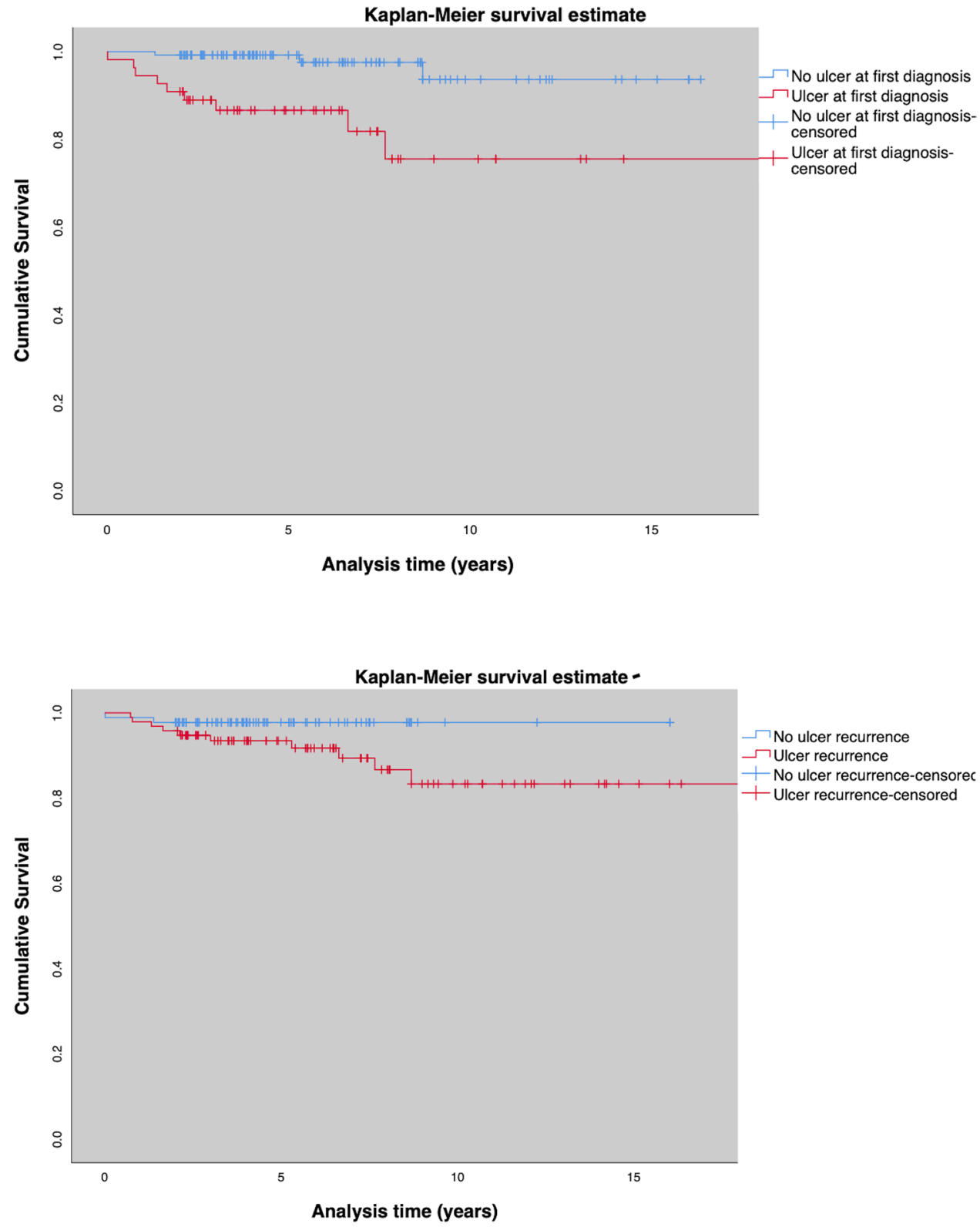

Table 4 Summary of minor and major amputations

\begin{tabular}{lc}
\hline & $\begin{array}{l}\text { Feet }(n, \%) \\
(\text { Cohort } n=184, \\
100 \%)\end{array}$ \\
\hline Minor amputations & $22(12.0 \%)$ \\
Toe level amputation & $16(8.7 \%)$ \\
Transmetatarsal amputation & $4(2.2 \%)$ \\
Bona-Jaeger amputation & $1(0.5 \%)$ \\
Pirogoff-Spitzy amputation & $1(0.5 \%)$ \\
Major amputations & $13(7.1 \%)$ \\
Transtibial amputation & $13(7.1 \%)$ \\
Transfemoral amputation & $0(0 \%)$ \\
No amputation & $149(81.0 \%)$ \\
\hline
\end{tabular}

Reactivation of CN occurs in 12.5-29.6\% [4, 31, 32, 35]. We detected reactivation clinically and radiologically (MRI) in $13.6 \%$. The comparable study of Jansen reported of $\mathrm{CN}$ reactivation in $23.3 \%$ over a shorter followup period [31]. The difference can be explained by the fact that reactivation in Jansen's study was defined by clinical symptoms (swelling, redness, temperature differences) alone. In our study, a positive MRI showing activity in the bones was a prerequisite for diagnosis of $\mathrm{CN}$ reactivation besides clinical signs. When relying on clinical symptoms alone, one may overestimate reactivation due to clinical signs of autonomic neuropathy. Most patients were detected in Eichenholtz stage $1(n=20,80 \%)$ and most 
Table 5 Details of $\mathrm{CN}$ reactivations

\begin{tabular}{|c|c|c|c|c|}
\hline & Total & $\mathrm{CN}$ reactivation & $\begin{array}{l}\text { No CN reactiva- } \\
\text { tion }\end{array}$ & $P$ \\
\hline Feet, $n(\%)$ & 184 & 25 (13.6) & $159(86.4)$ & \\
\hline Gender & & & & $.729^{a}$ \\
\hline Women & 57 & $7(12.3)$ & $50(87.7)$ & \\
\hline Men & 127 & $18(14.2)$ & $109(85.8)$ & \\
\hline Age & & 57 & 60 & $.1548^{\circ}$ \\
\hline BMI & & 31.1 & 28.4 & $.2310^{\circ}$ \\
\hline $\begin{array}{l}\text { Presence of } \\
\text { diabetes }\end{array}$ & & & & $.022^{\mathrm{a}}$ \\
\hline No diabetes & 53 & $4(7.5)$ & $49(92.5)$ & \\
\hline Diabetes Type I & 18 & $6(33.3)$ & $12(66.7)$ & \\
\hline $\begin{array}{l}\text { Diabetes Type } \\
\text { II }\end{array}$ & 113 & $15(13.3)$ & $98(86.7)$ & \\
\hline $\begin{array}{l}\text { Renal insuf- } \\
\text { ficiency }\end{array}$ & 42 & $9(21.4)$ & $33(78.6)$ & $.091^{\mathrm{a}}$ \\
\hline Smokers & 54 & $6(11.1)$ & 48 (88.9) & $.528^{\mathrm{a}}$ \\
\hline $\begin{array}{l}\text { Patients with } \\
\text { PAD }\end{array}$ & 40 & $7(17.5)$ & $33(82.5)$ & $.414^{\mathrm{a}}$ \\
\hline $\begin{array}{l}\text { Type of neuropa- } \\
\text { thy }\end{array}$ & & & & $.803^{\mathrm{a}}$ \\
\hline $\begin{array}{l}\text { Localization, } n \\
\quad(\%)\end{array}$ & & & & $.091^{\mathrm{a}}$ \\
\hline Sanders I & 25 & $7(28.0)$ & $18(72.0)$ & \\
\hline Sanders II & 87 & $9(10.3)$ & $78(89.7)$ & \\
\hline Sanders III & 56 & $9(16.1)$ & 47 (83.9) & \\
\hline Sanders IV & 11 & $0(0.0)$ & $11(100.0)$ & \\
\hline Sanders V & 5 & $0(0.0)$ & $5(100.0)$ & \\
\hline
\end{tabular}

${ }^{\text {a }}$ Pearson chi-square/Fisher's exact test; statistical significance is indicated in bold

reactivations occurred at the same localization as initially, which is in accordance to previous reports [4, 32]. Median time to reactivation was 1.9 (IQR 2.2) years. Presence of Diabetes was significantly associated with $\mathrm{CN}$ reactivation and could be seen more frequently in type 1 diabetics $(33 \%)$ than in type 2 diabetics $(13 \%)$ or in patients suffering from $\mathrm{CN}$ without Diabetes (8\%). To the best knowledge of the authors, this is new evidence and hints at different clinical courses depending on the etiology of $\mathrm{CN}$. Unfortunately, Bariteau`s analysis of idiopathic CN did not contain information on reactivation which would have been interesting for comparison [25].

Reports of contralateral $\mathrm{CN}$ development range from 0 to $75 \%$ [4, 27, 29-32, 35-37]. The study of Clohisy with bilateral involvement of $75 \%$ reports 18 patients and thus most likely overestimates contralateral involvement [37]. In our study, 26 patients (16.4\%) were affected bilaterally at the time of first $\mathrm{CN}$ diagnosis. During follow-up, another 25 patients $(18.8 \%)$ developed contralateral $\mathrm{CN}$. The median latency from diagnosis to contralateral $\mathrm{CN}$ was 1.1 years.
At the end of follow-up, 51 patients (32.1\%) were affected by bilateral $\mathrm{CN}$. The slight increase compared to previous reports might be explained by longer follow-up. Further, the larger study population might have led to a more realistic result: the two studies outmatching our length of follow-up included far less patients than the present work.

Plantar pressure ulcers occur in $38-70.2 \%$ in $\mathrm{CN}[9$, 27-30]. We detected ulcers in $72.3 \%$ of the affected feet at any stage of the clinical course. Most ulcers occurred at the toe or metatarsophalangeal joint level $(63.2 \%)$ while the midfoot level was affected in 30\%. Additionally, 6.8\% had plantar heel ulcers. Presence of PAD and smoking were significantly associated with ulcer development while the Sanders type was surprisingly not. Pakarinen et al. [29] reported ulcer recurrence in $40 \%$, while in Saltzmann et al. [30] series, $49 \%$ had ulcer recurrence and $29 \%$ even chronically recurrent ulcers. Ulcer recurrence occurred in $89(48.4 \%)$ feet in our series. $67.4 \%$ were located at the toe level and $28.1 \%$ at the midfoot level. Younger age (perhaps reflecting more physical activity), smoking, PAD, Diabetes, and Sanders type 2 were associated with ulcer recurrence. The ulcer rate of our collective is slightly higher than in the two studies with longer follow-up (Nilsen and Pakarinen) [27, 29], which include substantially less patients and therefore might have underestimated the number of ulcers. Further, some studies reported only ulcers that derived from plantar CN-related exostoses or elevated pressure [27, 31]. Our report includes ulcers at the toe level (both plantar ulcers and dorsal mostly PIP located ulcers) as well. Substracting those, only $26.3 \% \mathrm{CN}$ feet had at least one ulcer. Our rate of ulcer recurrence $(48.4 \%)$ is within the range of previous studies. Substracting toe ulcers, the recurrence rate would be $15.8 \%$. We attribute the low number of (recurrent) midfoot ulcers to consistent fitting of custom molded depth-insoles in $169 / 171$ non-amputated feet.

A significant number of $\mathrm{CN}$ feet need any surgical procedure (30-56.1\%) [25, 28-30]. In our study, $42.4 \%$ feet had at least one surgical procedure related to $\mathrm{CN}$ during follow-up. The median latency between first consultation and surgery was 1.5 (IQR 4.1) years. Removal of exostoses was necessary in $5.6 \%$, and realignment arthrodesis in $14.1 \%$ (internal realignment arthrodesis: $4.3 \%$, one-staged external realignment arthrodesis using the Ilizarov ring fixator: 9.8\%). Pakarinen et al. reported of exostoses removal in $33.3 \%$ and realignment arthrodesis in 10\% [29]. In Saltzman`s cohort, 54\% affected feet had any surgical procedure [30]. 11 of those were exostoses removals and 14 realignment arthrodesis procedures. There was no information on possible multiple procedures on the same foot thus making percentage calculation impossible. Bariteau reported the need of surgical treatment in $56.1 \%$ of the affected feet and the absolute number of 15 realignment fusion procedures at different levels, but also failed to report if multiple realignment procedures 
Table 6 Details of contralateral $\mathrm{CN}$

\begin{tabular}{|c|c|c|c|c|}
\hline & Total & No contralateral CN & Contralateral CN & $P$ \\
\hline Feet & 184 & 159 & 25 & \\
\hline Gender & & & & $0.014^{\mathrm{a}}$ \\
\hline Women & 57 & $44(77.2)$ & $13(22.8)$ & \\
\hline Men & 127 & $115(90.6)$ & $12(9.4)$ & \\
\hline Age & & 61 & 59 & $0.2595^{\mathrm{a}}$ \\
\hline BMI & & 28.7 & 28.6 & $0.8553^{\mathrm{a}}$ \\
\hline Presence of diabetes & & & & $0.377^{\mathrm{a}}$ \\
\hline No diabetes & 53 & 48 (90.6) & $5(9.4)$ & \\
\hline Diabetes Type I & 18 & $14(77.8)$ & $4(22.2)$ & \\
\hline Diabetes Type II & 113 & $97(85.8)$ & $16(14.2)$ & \\
\hline Renal insufficiency & 42 & $35(83.3)$ & $7(16.7)$ & $0.507^{\mathrm{a}}$ \\
\hline Smokers & 54 & $48(88.9)$ & $6(11.1)$ & $0.528^{\mathrm{a}}$ \\
\hline Patients with PAD & 40 & $35(87.5)$ & $5(12.5)$ & $0.821^{\mathrm{a}}$ \\
\hline Localization, $n(\%)$ & & & & $0.408^{\mathrm{a}}$ \\
\hline Sanders I & 25 & $24(96.0)$ & $1(4.0)$ & \\
\hline Sanders II & 87 & $72(82.8)$ & $15(17.2)$ & \\
\hline Sanders III & 56 & $49(87.5)$ & $7(12.5)$ & \\
\hline Sanders IV & 11 & $9(81.8)$ & $2(18.2)$ & \\
\hline Sanders V & 5 & $5(100.0)$ & $0(0.0)$ & \\
\hline
\end{tabular}

${ }^{\text {a } P e a r s o n ~ c h i-s q u a r e / F i s h e r ' s ~ e x a c t ~ t e s t ~}$

Table 7 Summary of ulcer development and ulcer recurrence

\begin{tabular}{|c|c|c|c|c|c|c|c|c|}
\hline & Total & Ulcer development & $\begin{array}{l}\text { No ulcer } \\
\text { development }\end{array}$ & $P$ & Total & Ulcer recurrence & No ulcer recurrence & $P$ \\
\hline Feet & 184 & 55 & 129 & & 184 & 95 & 89 & \\
\hline Gender & & & & $0.718^{\mathrm{a}}$ & & & & $0.438^{\mathrm{a}}$ \\
\hline Women & 57 & $16(28.1)$ & $41(71.9)$ & & 57 & $27(47.4)$ & $30(52.6)$ & \\
\hline Men & 127 & $39(30.7)$ & $88(69.3)$ & & 127 & $68(53.5)$ & $59(46.5)$ & \\
\hline Age & & 59 & 61 & $0.9241^{\mathrm{a}}$ & & 57 & 61 & $0.0380^{\mathrm{a}}$ \\
\hline BMI & & 28.9 & 28.2 & $0.0564^{\mathrm{a}}$ & & 28 & 29.1 & $0.7402^{\mathrm{a}}$ \\
\hline Presence of diabetes & & & & $0.280^{\mathrm{a}}$ & & & & $0.023^{\mathrm{a}}$ \\
\hline No diabetes & 53 & $13(24.5)$ & $40(75.5)$ & & 53 & $19(35.8)$ & $34(64.2)$ & \\
\hline Diabetes Type I & 18 & $8(44.4)$ & $10(55.6)$ & & 18 & $11(61.1)$ & $7(38.9)$ & \\
\hline Diabetes Type II & 113 & $34(30.1)$ & $79(69.9)$ & & 113 & $65(57.5)$ & $48(42.5)$ & \\
\hline Renal insufficiency & 42 & $14(33.3)$ & $28(66.7)$ & $0.579^{\mathrm{a}}$ & 42 & $24(57.1)$ & $18(42.9)$ & $0.416^{\mathrm{a}}$ \\
\hline Smokers & 54 & $25(46.3)$ & $29(53.7)$ & $0.002^{\mathrm{a}}$ & 54 & $35(64.8)$ & $19(35.2)$ & $0.021^{\mathrm{a}}$ \\
\hline Patients with PAD & 40 & $17(42.5)$ & $23(57.5)$ & $0.049^{\mathrm{a}}$ & 40 & $29(72.5)$ & $11(27.5)$ & $0.003^{\mathrm{a}}$ \\
\hline Localization, n (\%) & & & & $0.091^{\mathrm{a}}$ & & & & $0.003^{\mathrm{a}}$ \\
\hline Sanders I & 25 & $10(40.0)$ & $15(60.0)$ & & 25 & $15(60.0)$ & $10(40.0)$ & \\
\hline Sanders II & 87 & $32(36.8)$ & $55(63.2)$ & & 87 & $54(62.1)$ & 33 (37.9) & \\
\hline Sanders III & 56 & $10(17.9)$ & $46(82.1)$ & & 56 & $22(39.3)$ & $34(60.7)$ & \\
\hline Sanders IV & 11 & $2(18.2)$ & 9 (81.8) & & 11 & $1(9.1)$ & $10(90.9)$ & \\
\hline Sanders V & 5 & $1(20.0)$ & $4(80.0)$ & & 5 & $3(60.0)$ & $2(40.0)$ & \\
\hline
\end{tabular}

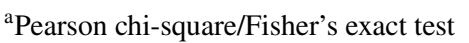

were necessary on the same foot [25]. The slighty higher amount of realignment arthrodesis procedures might have been influenced by higher surgical experience and therefore faster indication. It could also reflect demerits in indicating conservative therapy. Both smoking and presence of a midfoot ulcer were significantly associated with the need of 
Table 8 Summary if amputations

\begin{tabular}{|c|c|c|c|c|c|c|c|c|}
\hline & Total & Any amputations & No amputations & $P$ & Total & Major amputations & No major amputations & $P$ \\
\hline Feet & 183 & 35 & 148 & & 184 & 13 & 171 & \\
\hline Gender & & & & $0.113^{\mathrm{a}}$ & & & & $0.523^{\mathrm{a}}$ \\
\hline Women & 57 & $7(12.3)$ & $50(87.7)$ & & 57 & $3(5.3)$ & $54(94.7)$ & \\
\hline Men & 126 & $28(22.2)$ & $98(77.8)$ & & 127 & $10(7.9)$ & $117(92.1)$ & \\
\hline Age & & 59 & 60 & $0.3912^{\mathrm{a}}$ & & 51 & 60 & $0.0813^{\mathrm{a}}$ \\
\hline BMI & & 27.7 & 28.9 & $0.4585^{\mathrm{a}}$ & & 27.8 & 28.9 & $0.5534^{\mathrm{a}}$ \\
\hline Presence of diabetes & & & & $0.000^{\mathrm{a}}$ & & & & $0.000^{\mathrm{a}}$ \\
\hline No diabetes & 53 & $6(11.3)$ & $47(88.7)$ & & 53 & $1(1.9)$ & $52(98.1)$ & \\
\hline Diabetes Type I & 18 & $10(55.6)$ & $8(44.4)$ & & 18 & $6(33.3)$ & $12(66.7)$ & \\
\hline Diabetes Type II & 112 & $19(17.0)$ & $93(83.0)$ & & 113 & $6(5.3)$ & $107(94.7)$ & \\
\hline Renal insufficiency & 41 & $11(26.8)$ & $30(73.2)$ & $0.155^{\mathrm{a}}$ & 42 & $4(9.5)$ & $38(90.5)$ & $0.479^{\mathrm{a}}$ \\
\hline Smokers & 54 & $19(35.2)$ & $35(64.8)$ & $0.000^{\mathrm{a}}$ & 54 & $8(14.8)$ & $46(85.2)$ & $0.008^{\mathrm{a}}$ \\
\hline Patients with PAD & 40 & $14(35.0)$ & $26(65.0)$ & $0.004^{\mathrm{a}}$ & 40 & $5(12.5)$ & $35(87.5)$ & $0.129^{\mathrm{a}}$ \\
\hline Localization, n (\%) & & & & $0.688^{\mathrm{a}}$ & & & & $0.920^{\mathrm{a}}$ \\
\hline Sanders I & 25 & $6(24.0)$ & $19(76.0)$ & & 25 & $1(4.0)$ & $24(96.0)$ & \\
\hline Sanders II & 87 & $19(21.8)$ & $68(78.2)$ & & 87 & $7(8.0)$ & $80(92.0)$ & \\
\hline Sanders III & 55 & $8(14.5)$ & $47(85.5)$ & & 56 & $4(7.1)$ & $52(92.9)$ & \\
\hline Sanders IV & 11 & $1(9.1)$ & $10(90.9)$ & & 11 & $1(9.1)$ & $10(90.9)$ & \\
\hline Sanders V & 5 & $1(20.0)$ & $4(80.0)$ & & 5 & $0(0.0)$ & $5(100.0)$ & \\
\hline
\end{tabular}

aPearson chi-square/Fisher's exact test

Table 9 Studies reporting long-term follow-up listed by mean duration of follow up

\begin{tabular}{|c|c|c|c|c|c|c|c|c|c|}
\hline Study & $\begin{array}{l}\text { Follow up } \\
\text { (range) years }\end{array}$ & $\begin{array}{l}\text { Number } \\
\text { of patients } \\
\text { (feet) }\end{array}$ & $\begin{array}{l}\text { CA reactiva- } \\
\text { tion }\end{array}$ & $\begin{array}{l}\text { Contralateral } \\
\mathrm{CA}\end{array}$ & $\begin{array}{l}\text { Ulcer } \\
\text { develop- } \\
\text { ment }\end{array}$ & $\begin{array}{l}\text { Ulcer recur- } \\
\text { rence }\end{array}$ & $\begin{array}{l}\text { Any second- } \\
\text { ary surgical } \\
\text { procedure }^{f}\end{array}$ & $\begin{array}{l}\text { Major } \\
\text { amputa- } \\
\text { tions }\end{array}$ & $\begin{array}{l}\text { Mortal- } \\
\text { ity rate } \\
\text { (overall) }\end{array}$ \\
\hline Nilsen [25] & $8.9(2-16)$ & $62(74)$ & n.a & $17.9 \%$ & $64.9 \%$ & n.a & n.a & $14.9 \%$ & $19.4 \%$ \\
\hline $\begin{array}{l}\text { Pakarinen } \\
{[28]}\end{array}$ & $8(5-16)$ & $29(30)$ & n.a & $2.4 \%$ & $67 \%$ & $40 \%$ & $50 \%$ & $6.7 \%$ & $29.3 \%$ \\
\hline Present study & $6(2-20)$ & $159(184)$ & $13.6 \%$ & $32.1 \%$ & $72.3 \%$ & $48.4 \%$ & $42.4 \%$ & $7.1 \%$ & $13.2 \%$ \\
\hline Bariteau [2] & $5^{\mathrm{a}}$ & $59(82)^{b}$ & n.a & $39 \%$ & $37 \%^{\mathrm{c}}$ & n.a & $56.1 \%$ & $2.4 \%$ & n.a \\
\hline Fabrin [16] & $4(0.5-9.5)$ & $115(140)$ & $7.1 \% \mathrm{e}$ & $21.7 \% \mathrm{e}^{\mathrm{e}}$ & $37.9 \%$ & n.a & n.a. ${ }^{\mathrm{g}}$ & $1.4 \%$ & $1.7 \%$ \\
\hline $\begin{array}{l}\text { Christensen } \\
{[8]}\end{array}$ & $3.2^{\mathrm{a}}$ & 56 & $12.5 \%$ & n.a & n.a & n.a & n.a & $0 \%$ & $0 \%^{\mathrm{d}}$ \\
\hline Jansen [20] & $2.6(0.25-14)$ & $173(176)$ & $23.3 \%$ & $5.8 \%$ & $67 \%$ & n.a & n.a & $11.9 \%$ & $39 \%$ \\
\hline $\begin{array}{c}\text { Saltzmann } \\
\text { [37] }\end{array}$ & $0.8(0.5-18.5)$ & $115(127)$ & n.a & $10.5 \%$ & $58.5 \%$ & $49 \%$ & $54 \%$ & $11.8 \%$ & $20 \%$ \\
\hline
\end{tabular}

The studies of Bergis [3] and O'Loughlin [26] were excluded due to inconclusive information on duration of follow-up

Bold $=$ highest number; n.a. = information not provided

${ }^{a}$ Range not provided

${ }^{b}$ Paper reports inconsistent numbers: it states 59 patients but lists 23 men and 37 women (=60 patients)

${ }^{c}$ Only number at initial presentation given, no details over the course of follow up

${ }^{\mathrm{d}}$ Death was an exclusion criterion

ePercentage not given but calculated based on absulte numbers provided

${ }^{\mathrm{f}}$ Reflects percentage of feet, does not contain multiple procedures on the same foot

${ }^{\mathrm{g}} 6 / 132(4.5 \%)$ feet had either major amputation or realignment arthrodesis, 10/108 (9.3\%) patients had minor surgical procedures without information on the amount of affected feet 
realignment arthrodesis. Interestingly, neither the Sanders type nor Diabetes were significantly associated with the need of realignment arthrodesis.

Overall amputation rates for patients of $20-25.7 \%$ are listed in the literature [27, 28]. In the present work, 19.1\% feet needed an amputation procedure: $7.1 \%$ were major amputations and $12 \%$ minor amputations. The necessity of major amputations varies from 1.4 to $22.5 \%$ in the literature $[4,25,27-31,36,38]$. Fabrin's $1.4 \%$ major amputation is not comparable to our data as it can be explained by the shorter follow-up period, and by inclusion of patients with follow-up periods of less than 2 years, who might have been amputated elsewhere [4]. Bariteau's 2.4\% might stem from the shorter follow-up and-more interestingly-from inclusion of idiopathic CN only [25]. Subanalysis of our patients with major amputation revealed that none of the 27 patients with idiopathic $\mathrm{CN}$, but $9.3 \%$ of diabetic $\mathrm{CN}$ needed major amputation. Statistically presence of Diabetes was significantly associated with the need of major amputation besides active smoking. Neither the Sanders type nor presence of a midfoot ulcer were associated with major amputation. Thus, major amputation must be expected in any anatomical location. Elmarsafi et al. investigated risk factors for major amputation after $\mathrm{CN}$ reconstructive surgery [39]. They found a major amputation rate of $17.2 \%$ and identified PAD, renal disease, postoperative delayed healing (defined as nonhealing $>30$ days), postoperative osteomyelitis, postreconstruction nonunions, the development of new $\mathrm{CN}$ sites, and increased $\mathrm{HbA} 1 \mathrm{c}$ as risk factors for major amputation.

In comparison to surgical literature, we could find similar rates in limb salvage (92.9\%) compared to studies with similar length of follow-up: $93.7 \%$ limbs could be saved according to Fragomen's series of 16 reconstructed feet[40]. Another recent study by Spraul et al. reported a limb salvage rate of 89\% while using the Hoffmann-external Fixator[41]. In a recent study with a mean of 35 months follow-up that analyzed the outcome of a one-staged reconstruction procedure using the Ilizarov principles, Wirth et al. reported successful limb salvage in 93\% [42]. Ettinger et al. (31.3 months followup) reported a limb salvage rate of $94.8 \%$ in their series of surgically reconstructed $\mathrm{CN}$ ankles[43]. The same group published a case series (18 months follow-up) of tibiocalcaneal arthrodesis in $\mathrm{CN}$-related talar breakdown, with $91.7 \%$ of the affected limbs being saved [44]. Pinzur et al. had a success rate of $97.3 \%$ limb salvage but had substantially less follow-up with 12 months [45]. Reinke et al. reported successful limb salvage using the Ilizarov principles in all five cases of $\mathrm{CN}$ with talar body necrosis after a follow-up of 27 months[46]. There were no differences in major amputations between the studies by Hegewald et al. [47], Ford et al. [48] and our study ( $p=0.730$ and $p=0.125$, respectively; test on equality of proportions), but our study showed lower proportions of major amputations compared to Eschler et al. [49] and Elmarsafi et al. [39] (7.1\% versus $28.6 \%, p=0.030$ and $7.1 \%$ versus $17.2 \%, p=0.002$, respectively). Compared to the studies by Hegewald et al. [47], Eschler et al. [49], and Elmarsafi et al. [39], our mean time to amputation was significantly different $(p=0.020, p=0.026$, and $p=0.006$, respectively; $t$ tests) with amputations occurring after a longer time frame in our study. In comparison to the study by Ford et al., our mean time to amputation showed a trend for differences $(p=0.056)$, indicating a longer major amputation-free survival as well. However, due to potential patient differences, these comparisons need to be interpreted with care.

\section{Conclusion}

With conservative therapy of $\mathrm{CN}$, limb loss can be prevented in almost $93 \%$ after 5.2 years. Patients and physicians must be prepared for a high probability of facing complications. In patients with diabetic $\mathrm{CN}$, reactivation of $\mathrm{CN}$ is more common than in non-diabetic CN. Diabetics were at an enhanced risk of major amputation and of developing ulcer recurrence. Smoking was significantly associated with the development of ulcers and necessity of amputation procedures. Therefore, when dealing with $\mathrm{CN}$, physicians must take special care if the etiology of $\mathrm{CN}$ is of diabetic nature and must make every effort to convince patients to stop smoking.

Supplementary Information The online version contains supplementary material available at https://doi.org/10.1007/s00402-021-03881-5.

Acknowledgements We are indebted to the study nurses and secretaries of the Unit for Clinical and Applied Research (UCAR) of Balgrist University Hospital, for their invaluable help in the follow-up of our study patients and the redaction of protocols.

Funding Open Access funding provided by Universität Zürich.. The authors received no financial support for the research, authorship, and/ or publication of this article.

\section{Declarations}

Ethical review committee statement Attached below.

Location of work statement The study was conducted at Balgrist University Hospital, Zurich Switzerland. It served as the doctoral thesis of Ms. Gratwohl.

Conflict of interest Each author certifies that he or she has no commercial associations (eg, consultancies, stock ownership, equity interest, patent/licensing arrangements, etc.) that might pose a conflict of interest in connection with the submitted article.

Open Access This article is licensed under a Creative Commons Attribution 4.0 International License, which permits use, sharing, adaptation, distribution and reproduction in any medium or format, as long as you give appropriate credit to the original author(s) and the source, provide a link to the Creative Commons licence, and indicate if changes were made. The images or other third party material in this article are 
included in the article's Creative Commons licence, unless indicated otherwise in a credit line to the material. If material is not included in the article's Creative Commons licence and your intended use is not permitted by statutory regulation or exceeds the permitted use, you will need to obtain permission directly from the copyright holder. To view a copy of this licence, visit http://creativecommons.org/licenses/by/4.0/.

\section{References}

1. Charcot J (1868) Sur quelques arthropathies qui paraissent dépendre d'une lésion du cerveau ou de la moelle épinière. Arch Physiol Norm et Pathol 1:161-178

2. Pinzur MS (1999) Benchmark analysis of diabetic patients with neuropathic (Charcot) foot deformity. Foot Ankle Int 20(9):564567. https://doi.org/10.1177/107110079902000905

3. Rajbhandari SM, Jenkins RC, Davies C, Tesfaye S (2002) Charcot neuroarthropathy in diabetes mellitus. Diabetologia 45(8):10851096. https://doi.org/10.1007/s00125-002-0885-7

4. Fabrin J, Larsen K, Holstein PE (2000) Long-term follow-up in diabetic Charcot feet with spontaneous onset. Diabetes Care 23(6):796-800. https://doi.org/10.2337/diacare.23.6.796

5. Stuck RM, Sohn MW, Budiman-Mak E, Lee TA, Weiss KB (2008) Charcot arthropathy risk elevation in the obese diabetic population. Am J Med 121(11):1008-1014. https://doi.org/10.1016/j. amjmed.2008.06.038

6. Koeck FX, Bobrik V, Fassold A, Grifka J, Kessler S, Straub RH (2009) Marked loss of sympathetic nerve fibers in chronic Charcot foot of diabetic origin compared to ankle joint osteoarthritis. J Orthop Res 27(6):736-741. https://doi.org/10.1002/jor.20807

7. Frykberg RG, Kozak GP (1978) Neuropathic arthropathy in the diabetic foot. Am Fam Physician 17(5):105-113

8. Blume PA, Sumpio B, Schmidt B, Donegan R (2014) Charcot neuroarthropathy of the foot and ankle: diagnosis and management strategies. Clin Podiatr Med Surg 31(1):151-172. https:// doi.org/10.1016/j.cpm.2013.09.007

9. Armstrong DG, Todd WF, Lavery LA, Harkless LB, Bushman TR (1997) The natural history of acute Charcot's arthropathy in a diabetic foot specialty clinic. J Am Podiatr Med Assoc 87(6):272278. https://doi.org/10.7547/87507315-87-6-272

10. Petrova NL, Edmonds ME (2008) Charcot neuro-osteoarthropathy-current standards. Diabetes Metab Res Rev 24(Suppl 1):S5861. https://doi.org/10.1002/dmrr.846

11. Eichenholtz SN (1966) Charcot joints. C. C, Thomas, Springfield, Ill

12. Shibata T, Tada K, Hashizume C (1990) The results of arthrodesis of the ankle for leprotic neuroarthropathy. J Bone Joint Surg Am 72(5):749-756

13. Sanders L (1991) Diabetic neuropathic osteoarthropathy: the Charcot foot. The high risk foot in diabetes mellitus. Diabetes Care 34(9):2123-2129

14. Dodd A, Daniels TR (2018) Charcot neuroarthropathy of the foot and ankle. J Bone Joint Surg Am 100(8):696-711. https://doi.org/ 10.2106/jbjs. 17.00785

15. Khan A, Petropoulos IN, Ponirakis G, Menzies RA, Chidiac O, Pasquier J, Abi Khalil C, Talal TK, Malik RA (2018) Corneal confocal microscopy detects severe small fiber neuropathy in diabetic patients with Charcot neuroarthropathy. J Diabetes Investig 9(5):1167-1172. https://doi.org/10.1111/jdi.12806

16. Hingsammer AM, Bauer D, Renner N, Borbas P, Boeni T, Berli M (2016) Correlation of systemic inflammatory markers with radiographic stages of charcot osteoarthropathy. Foot Ankle Int 37(9):924-928. https://doi.org/10.1177/1071100716649173

17. Botek G, Figas S, Narra S (2019) Charcot neuroarthropathy advances: understanding pathogenesis and medical and surgical management. Clin Podiatr Med Surg 36(4):663-684. https://doi. org/10.1016/j.cpm.2019.07.002

18. Ramanujam CL, Facaros Z (2011) An overview of conservative treatment options for diabetic Charcot foot neuroarthropathy. Diabet Foot Ankle. https://doi.org/10.3402/dfa.v2i0.6418

19. Renner N, Wirth SH, Osterhoff G, Böni T, Berli M (2016) Outcome after protected full weightbearing treatment in an orthopedic device in diabetic neuropathic arthropathy (Charcot arthropathy): a comparison of unilaterally and bilaterally affected patients. BMC Musculoskelet Disord 17(1):504. https://doi.org/10.1186/ s12891-016-1357-4

20. Güven MF, Karabiber A, Kaynak G, Oğüt T (2013) Conservative and surgical treatment of the chronic Charcot foot and ankle. Diabet Foot Ankle. https://doi.org/10.3402/dfa.v4i0.21177

21. Pinzur MS (2016) Surgical treatment of the Charcot foot. Diabetes Metab Res Rev 32(Suppl 1):287-291. https://doi.org/10.1002/ dmrr.2750

22. Pinzur MS, Schiff AP (2018) Deformity and clinical outcomes following operative correction of Charcot foot: a new classification with implications for treatment. Foot Ankle Int 39(3):265-270. https://doi.org/10.1177/1071100717742371

23. Schneekloth BJ, Lowery NJ, Wukich DK (2016) Charcot neuroarthropathy in patients with diabetes: an updated systematic review of surgical management. J Foot Ankle Surg 55(3):586-590. https://doi.org/10.1053/j.jfas.2015.12.001

24. Larsson J, Apelqvist J, Agardh CD, Stenström A (1995) Decreasing incidence of major amputation in diabetic patients: a consequence of a multidisciplinary foot care team approach? Diabet Med 12(9):770-776. https://doi.org/10.1111/j.1464-5491.1995. tb02078.x

25. Bariteau JT, Tenenbaum S, Rabinovich A, Brodsky JW (2014) Charcot arthropathy of the foot and ankle in patients with idiopathic neuropathy. Foot Ankle Int 35(10):996-1001. https://doi. org/10.1177/1071100714543649

26. Larsen K, Fabrin J, Holstein PE (2001) Incidence and management of ulcers in diabetic Charcot feet. J Wound Care 10(8):323328. https://doi.org/10.12968/jowc.2001.10.8.26113

27. Nilsen FA, Molund M, Hvaal KH (2018) High incidence of recurrent ulceration and major amputations associated with Charcot foot. J Foot Ankle Surg 57(2):301-304. https://doi.org/10.1053/j. jfas.2017.10.008

28. O'Loughlin A, Kellegher E, McCusker C, Canavan R (2017) Diabetic charcot neuroarthropathy: prevalence, demographics and outcome in a regional referral centre. Ir J Med Sci 186(1):151156. https://doi.org/10.1007/s11845-016-1508-5

29. Pakarinen TK, Laine HJ, Mäenpää H, Mattila P, Lahtela J (2009) Long-term outcome and quality of life in patients with Charcot foot. Foot Ankle Surg 15(4):187-191. https://doi.org/10.1016/j. fas.2009.02.005

30. Saltzman CL, Hagy ML, Zimmerman B, Estin M, Cooper R (2005) How effective is intensive nonoperative initial treatment of patients with diabetes and Charcot arthropathy of the feet? Clin Orthop Relat Res 435:185-190. https://doi.org/10.1097/00003 086-200506000-00026

31. Jansen RB, Jørgensen B, Holstein PE, Møller KK, Svendsen OL (2018) Mortality and complications after treatment of acute diabetic Charcot foot. J Diabetes Complications 32(12):1141-1147. https://doi.org/10.1016/j.jdiacomp.2018.09.013

32. Osterhoff G, Böni T, Berli M (2013) Recurrence of acute Charcot neuropathic osteoarthropathy after conservative treatment. Foot Ankle Int 34(3):359-364. https://doi.org/10.1177/1071100712 464957

33. Rudrappa S, Game F, Jeffcoate W (2012) Recurrence of the acute Charcot foot in diabetes. Diabet Med 29(6):819-821. https://doi. org/10.1111/j.1464-5491.2011.03539.x 
34. Bergis D, Bergis PM, Hermanns N, Zink K, Haak T (2014) Coronary artery disease as an independent predictor of survival in patients with type 2 diabetes and Charcot neuro-osteoarthropathy. Acta Diabetol 51(6):1041-1048. https://doi.org/10.1007/ s00592-014-0669-9

35. Christensen TM, Gade-Rasmussen B, Pedersen LW, Hommel E, Holstein PE, Svendsen OL (2012) Duration of off-loading and recurrence rate in Charcot osteo-arthropathy treated with less restrictive regimen with removable walker. J Diabetes Complications 26(5):430-434. https://doi.org/10.1016/j.jdiacomp.2012.05. 006

36. Berli M, Vlachopoulos L, Leupi S, Böni T, Baltin C (2017) Treatment of Charcot Neuroarthropathy and osteomyelitis of the same foot: a retrospective cohort study. BMC Musculoskelet Disord 18(1):460. https://doi.org/10.1186/s12891-017-1818-4

37. Clohisy DR, Thompson RC Jr (1988) Fractures associated with neuropathic arthropathy in adults who have juvenile-onset diabetes. J Bone Joint Surg Am 70(8):1192-1200

38. Doria M, Viadé J, Palomera E, Pérez R, Lladó M, Costa E, Huguet T, Reverter JL, Serra-Prat M, Franch-Nadal J, Mauricio D (2018) Short-term foot complications in Charcot neuroarthropathy: a retrospective study in tertiary care centres in Spain. Endocrinol Diabetes Nutr 65(9):479-485. https://doi.org/10.1016/j.endinu. 2018.06.004

39. Elmarsafi T, Anghel EL, Sinkin J, Cooper PS, Steinberg JS, Evans KK, Kim PJ, Attinger CE (2019) Risk factors associated with major lower extremity amputation after osseous diabetic Charcot reconstruction. J Foot Ankle Surg 58(2):295-300. https://doi.org/ 10.1053/j.jfas.2018.08.059

40. Fragomen AT, Borst E, Schachter L, Lyman S, Rozbruch SR (2012) Complex ankle arthrodesis using the Ilizarov method yields high rate of fusion. Clinical Orthopaedics and Related Research 470(10):2864-2873. https://doi.org/10.1007/s11999-012-2470-9

41. Spraul AMS, Schönbach AM, Müller N, Müller UA, Koller A, Spraul M (2020) Long-term outcome of persons with diabetic and non-diabetic neuro-osteoarthropathy after foot correction using external fixation. Diabet Med 15:e14404. https://doi.org/10.1111/ dme.14404

42. Wirth SH, Viehofer AF, Tondelli T, Hartmann R, Berli MC, Boni T, Waibel FWA (2020) Mid-term walking ability after Charcot foot reconstruction using the Ilizarov ring fixator. Arch Orthop
Trauma Surg 140(12):1909-1917. https://doi.org/10.1007/ s00402-020-03407-5

43. Ettinger S, Plaass C, Claassen L, Stukenborg-Colsman C, Yao D, Daniilidis K (2016) Surgical management of charcot deformity for the foot and ankle-radiologic outcome after internal/external fixation. J Foot Ankle Surg 55(3):522-528. https://doi.org/10.1053/j. jfas.2015.12.008

44. Ettinger S, Stukenborg-Colsman C, Plaass C, Yao D, Claassen L, Berger S, Waizy H, Becher CM, Daniilidis K (2016) Tibiocalcaneal arthrodesis as a limb salvage procedure for complex hindfoot deformities. Arch Orthop Trauma Surg 136(4):457-462. https:// doi.org/10.1007/s00402-016-2420-1

45. Pinzur MS, Gil J, Belmares J (2012) Treatment of osteomyelitis in Charcot foot with single-stage resection of infection, correction of deformity, and maintenance with ring fixation. Foot Ankle Int 33(12):1069-1074. https://doi.org/10.3113/fai.2012.1069

46. Reinke C, Lotzien S, Yilmaz E, Hanusrichter Y, Ull C, Baecker H, Schildhauer TA, Gessmann J (2021) Tibiocalcaneal arthrodesis using the Ilizarov fixator in compromised hosts: an analysis of 19 patients. Arch Orthop Trauma Surg. https://doi.org/10.1007/ s00402-021-03751-0

47. Hegewald KW, Wilder ML, Chappell TM, Hutchinson BL (2016) Combined internal and external fixation for diabetic Charcot reconstruction: a retrospective case series. J Foot Ankle Surg 55(3):619-627. https://doi.org/10.1053/j.jfas.2015.04.016

48. Ford SE, Cohen BE, Davis WH, Jones CP (2019) Clinical outcomes and complications of midfoot Charcot reconstruction with intramedullary beaming. Foot Ankle Int 40(1):18-23. https://doi. org/10.1177/1071100718799966

49. Eschler A, Wussow A, Ulmar B, Mittlmeier T, Gradl G (2014) Intramedullary medial column support with the Midfoot Fusion Bolt (MFB) is not sufficient for osseous healing of arthrodesis in neuroosteoarthropathic feet. Injury 45:S38-S43. https://doi.org/ 10.1016/j.injury.2013.10.037

Publisher's Note Springer Nature remains neutral with regard to jurisdictional claims in published maps and institutional affiliations. 